\title{
Three new species of Achrysocharoides Girault (Hymenoptera: Eulophidae) parasitoids of Phyllonorycter spp. (Lepidoptera: Gracillariidae) on Acer platanoides and Robinia pseudoacacia
}

\author{
CHRISTER HANSSON \& EKATERINA SHEVTSOVA \\ Department of Biology, Zoology, Lund University, Helgonavägen 3, SE- 22362 Lund, Sweden \\ E-mail: Christer.Hansson@cob.lu.se; Ekaterina.Shevtsova@cob.lu.se
}

\begin{abstract}
Three new species of Achrysocharoides are described, one from northern Europe, A. platanoidae sp. nov., one from central Europe and the U.S.A., A. robiniae sp. nov., and one from the U.S.A., A. robinicolus sp. nov. The descriptions are based on material reared from microlepidopterans of the genus Phyllonorycter Hübner (Gracillariidae): A. platanoidae from P. platanoidella (Joannis) on Acer platanoides, and A. robiniae and A. robinicolus from P. robiniella (Clemens) on Robinia pseudoacacia (black locust). The new species are very similar to previously described species, A. platanoidae to A. acerianus (Askew), and A. robiniae and A. robinicolus to A. gahani (Miller), but they are shown here to differ from their sibling species both in biology and in external morphology. The host of $A$. robiniae and A. robinicolus, $P$. robiniella, is a serious pest on the black locust tree in Europe, and the descriptions with diagnoses of these two species, and their scientific names, introduced here will aid the biological control efforts of this pest.
\end{abstract}

Key words: taxonomy, Chalcidoidea, Entedoninae, leafminer parasitoids, Achrysocharoides acerianus, Achrysocharoides platanoidae, Achrysocharoides robiniae, Achrysocharoides robinicolus, Achrysocharoides gahani, Phyllonorycter robiniella, Phyllonorycter geniculella, Phyllonorycter platanoidella, black locust, Acer pseudoplatanus, biological control

\section{Introduction}

Achrysocharoides Girault (Chalcidoidea: Eulophidae: Entedoninae) was originally described based on an Australian species (Girault 1913a) but its main distribution is now known to be the northern hemisphere (Bouček \& Askew 1968; Burks 1979; Kamijo 1990a, 1990b, 1991). Worldwide, Achrysocharoides comprises 54 described species. Including the new species described here, 22 species are now known from Europe and 20 from North America.

Species of Achrysocharoides are unusually host specific. Most species of Entedoninae are polyphagous with broad host ranges (Askew \& Shaw 1979; Hansson 1985), but Achrysocharoides species select their hosts among a very limited number of host species. They are larval endoparasitoids of leaf mining moths of the family Gracillariidae (Lepidoptera), mainly of species in Phyllonorycter Hübner (Askew \& Ruse 1974). Apart from choosing their hosts from a very narrow range of moth species, the hosts are usually selected from only a few and related plant genera (Lopez-Vaamonde et al. 2005).

Two of the Achrysocharoides species described here are parasitoids of Phyllonorycter robiniella (Clemens), a small moth native to North America that is monophagous on black locust, Robinia pseudoacacia (Šefrov 2002). The black locust is a legume tree native to central and eastern U.S.A. (Mabberley 1997) that was introduced into most European countries (Polunin 1969). The introductions started in the beginning of the $17^{\text {th }}$ century (Stojanović \& Marković 2005) and the tree was introduced as an ornamental, for its resistant wood and fragrant flowers (used for honey and perfumery) (Polunin 1969). It is an economically important plant especially in central Europe (Melika et al. 2006). Since its introduction in Europe this tree has been considered free from serious pests. However, in 1983 P. robiniella was discovered in Switzerland (Whitebread 